\title{
Le déclin de la recherche en France : la radioprotection ne fait pas exception?
}

Le journal Le Monde a publié récemment un numéro spécial dédié aux raisons du déclin de la recherche en France (Le Monde, 2021). Sur la base des résultats préliminaires de l'Observatoire des Sciences et Techniques, Le Monde souligne «le flétrissement du prestige français, en matière de publications, de moyens financiers, de salaires, et des fractures apparaissent au sein même de la communauté scientifique». Dans le même temps, le nombre des recrutements a très significativement diminué et l'âge d'obtention des postes de chercheurs titulaires a augmenté alors que dans le passé, les postes de titulaires étaient considérés comme une des forces du système de recherche en France.

Dans ce numéro, un article signé par six radiobiologistes réputés, et intitulé «La radiobiologie française : historique, constats et enjeux » est un cri d'alarme, parfaitement documenté, poussé par ses auteurs, confrontés depuis une trentaine d'années à la dégradation progressive mais ininterrompue des moyens matériels, humains et de formation alloués à la recherche en radiobiologie tant fondamentale qu'appliquée (Foray et al., 2021). Les auteurs de cet article, au vu des tendances qui, selon eux, marginalisent la radiobiologie, redoutent que les recherches sur les effets radio induits ou celles visant à l'amélioration de la radiologie diagnostique et de la médecine nucléaire ou de la radiothérapie externe ou métabolique vectorisée, ne régressent en France en deçà d'un seuil critique. Et ce, au détriment de la collectivité. Cela est tout à fait funeste puisque la radiobiologie a fait et continue de faire des contributions fondamentales à la science (Kirsch et al., 2017; Foray et al., 2021).

De nombreuses disciplines autres que la radiobiologie participent également à la radioprotection : épidémiologie, dosimétrie biologique et physique, toxicologie, écotoxicologie et radioprotection de l'environnement (Bourguignon et al., 2017a). Les recherches dans ces domaines sont essentielles pour l'optimisation de la radioprotection dans toutes les situations, en particulier en ce qui concerne les expositions aux faibles doses, par exemple en médecine, avec le radon ou dans les situations post accidentelles. À notre connaissance, il n'y a pas d'analyses claires de la situation des ressources de la recherche dans tous ces domaines de la radioprotection qui soit comparable à l'inventaire effectué en radiobiologie par Foray et al. De plus, bien que la radioprotection soit tout à fait complémentaire de la sûreté nucléaire, les budgets alloués sont significativement différents, la radioprotection étant de très loin la plus pauvre des deux. Cette situation n'est pas tenable.

Alors pouvons-nous dire que la recherche en radioprotection ne fait pas exception au déclin de la recherche en France? Probablement pas!

Comme signe positif, des articles significatifs en radioprotection, venant en majorité d'institutions françaises spécialisées, ont été publiés dans Radioprotection dans les deux dernières années par exemple:

- La vertébroplastie percutanée sous scanner avec un système de navigation assistée par ordinateur (Teriitehau et al., 2020);

- L'optimisation des doses scanners chez les enfants (Malchair et Maccia, 2020);

- La radiobiologie des très fortes doses par fraction: connaissances en 2020 et nouvelles modélisations précliniques (Bertho et al., 2021);

- Les techniques de modélisation inverses pour évaluer les rejets atmosphériques accidentels des centrales nucléaire (Saunier et al., 2020);

- La gestion des denrées contaminées au Japon depuis l'accident de Fukushima (Maître et al., 2020);

- L'exposition aux champs magnétiques de fréquence extrêmement basses (Magne et al., 2020).

Comme signe négatif, aucun des articles de recherche cités ci-dessus ne provenait d'institutions académiques!

Pour conclure, la radioprotection est un domaine multidisciplinaire dans lequel la recherche doit être soutenue à tous les niveaux et dans tous les domaines. Les articles sur les moyens matériels, humains et de formation alloués à la recherche en radioprotection sont les bienvenus dans Radioprotection.

\section{The decline of scientific research in France: radiological protection is no exception?}

The journal Le Monde published recently a special issue dedicated to the reasons of the decline of the research in France (Le Monde, 2021). On the basis of preliminary results from the Observatory of Sciences and Techniques, Le Monde quote the withering of the French prestige regarding the number of publications, financial resources, salaries, and the appearance of fractures in the scientific 
community. At the same time, the number of recruitments has quite significantly decreased and the age of getting tenure positions of researchers increased: in the past incumbent positions were considered as a strength of the French system of research!

In this issue, an article from distinguished French radiation biologists, entitled "French radiobiology: history, findings and challenges" is a cry of alarm, perfectly documented, pushed by its authors, confronted for thirty years with the gradual but uninterrupted degradation of material, human and training resources, allocated to research in both basic and applied radiobiology (Foray et al., 2021). The authors of this article, in view of the trends which, according to them, marginalize radiobiology, fear that research on induced radiobiological effects or those aimed at improving diagnostic radiology or radiotherapy decline in France below a critical threshold. And this to the detriment of the community. This is quite disastrous since radiation biology has brought and continue to bring critical contributions to science (Kirsch et al., 2017; Foray et al., 2021).

Many disciplines other than radiobiology contribute significantly to radiological protection: epidemiology, biological and physical dosimetry, toxicology, ecotoxicology, and psychosocial evaluations (Bourguignon et al., 2017b). Research in these domains are critical for an optimized radiological protection in all situations, especially regarding exposure at low doses, e.g., in medicine, with radon or in post accidental phase. To our knowledge, there are no clear analysis of the situation regarding the resources of research in all these domains of radiological protection which would be comparable to the inventory made in radiobiology by Foray et al. Furthermore, although radiological protection is quite complementary of nuclear safety, the budgets allocated are significantly different, radiological protection being by far the poorer of the two. This situation is not sustainable.

Thus, can we say that radiological protection research is no exception in the decline of research in France? Probably not!

As a positive sign, significant articles in radiological protection, coming in majority from specialized French institutions, have been published in Radioprotection in the last two years, for example:

- Percutaneous CT vertebroplasty with of a computer-assisted navigation system (Teriitehau et al., 2020);

- Optimization of CT scanner dose in children (Malchair and Maccia, 2020);

- Radiobiology of high doses per fraction: knowledge in 2020 and new preclinical models (Bertho et al., 2021);

- Inverse modeling techniques to assess the atmospheric accidental release from a nuclear power plant (Saunier et al., 2020);

- The management of contaminated goods in Japan since the Fukushima accident (Maître et al., 2020);

- Exposure to extremely low frequency magnetic field (Magne et al., 2020).

As a negative sign, none of these research articles came from French academic institutions.

To conclude, radiological protection is a multidisciplinary field in which research need to be steadily supported at all levels. We welcome in Radioprotection articles on material, human and training resources allocated to radiological protection.

\section{Références}

Bertho A, Dos Santos M, François A, Milliat F. 2021. Radiobiologie des très fortes doses par fraction : connaissances en 2020 et nouvelles modélisations précliniques. Radioprotection 56(1): 11-24.

Bourguignon M, Bérard P, Bertho JM, Farah J, Mercat C, Radioprotection Editorial Board. 2017a. Radioprotection: quel avenir? Radioprotection 52(1): 13-20.

Bourguignon M, Bérard P, Bertho JM, Farah J, Mercat C, Radioprotection Editorial Board. 2017b. What's next in Radioprotection? Radioprotection 52(1): 21-28.

Foray N, Averbeck D, Cosset JM, Drouet M, Favaudon V, Masse R. 2021. La radiobiologie française: historique, constats et enjeux. Radioprotection 56(4): 257-267.

Kirsch DG, et al. 2017. The future of radiobiology. JNCI. https://doi.org/10.1093/jnci/djx213.

Le Monde. 2021. Numéro spécial 10 ans: Science et médecine. 29 septembre 2021.

Magne I, Souques M, Courouve L, Duburcq A, Remy E, Cabanes P-A. 2020. Exposure of adults to extremely low frequency magnetic field in France: results of the EXPERS study. Radioprotection 55(1): 39-50.

Maître M, Croüail P, Durand V, Lecomte J-F, Charron S, Schneider T. 2020. The management of contaminated goods in Japan since the Fukushima accident. Radioprotection 55(1): 17-28.

Malchair F, Maccia C. 2020. Practical advices for optimal CT scanner dose in children. Radioprotection 55(2): $123-134$.

Saunier O, Korsakissok I, Didier D, Doursout T, Mathieu A. 2020. Real-time use of inverse modeling techniques to assess the atmospheric accidental release from a nuclear power plant. Radioprotection 55(2): 107-115.

Teriitehau C, Rabeh H, Pessis E, Sénéchal Q, Besse F, Bravetti M. 2020. Reduction of patient radiation dose during percutaneous CT vertebroplasty: Impact of a new computer-assisted navigation (CAN) system. Radioprotection 55(1): 11-16. 